\title{
Class 3 antiarrhythmic action in man' Observations from monophasic action potential recordings and amiodarone treatment
}

\author{
S. Bertil Olsson, Leif Brorson, and Ed Varnauskas \\ From the Department of Cardiology, Medical Clinic I, Sahlgrenska Hospital, \\ Göteborg, Sweden
}

Nine patients with different supraventricular tachyarrhythmias were treated orally with amiodarone (a Class 3 antiarrhythmic drug) according to a standardized protocol. Eight patients had subjective or objective beneficial antiarrhythmic effects from the drug. The treatment was discontinued in 2 patients due to corneal opacifications. In all patients right atrial monophasic action potentials were recorded with the bipolar suction electrode technique before treatment and in 8 patients after at least 4 weeks of treatment. The atrial monophasic action potential was prolonged in all patients after amiodarone treatment and increased on average from $234 \mathrm{msec}$ to $308 \mathrm{msec}$. The findings demonstrate the specific mode of action of the drug and the use of monophasic action potential recordings to identify patients who, theoretically, could benefit from antiarrhythmic drugs whose action is to delay repolarization.

It is now generally accepted that various antiarrhythmic drugs have quite different modes of action. A recently suggested classification (Vaughan Williams, 1973) distinguishes between at least three separate effects. Class I mode of action is the one exhibited by quinidine, procainamide, and lignocaine among others. It is recognized from recordings of transmembrane potentials from heart muscle cells (Ling and Gerard, 1949) and appears in such recordings as a depression of the maximal rate of depolarization of the cell membrane. The class 2 mode of action consists of inhibition of adrenergic activity, either at the receptor site or by interference with the release of sympathetic transmitters. The class 3 mode of action is also demonstrated with the micro-electrode technique. This mechanism is a prolongation of the action potential, a delayed repolarization. Such a mechanism has been shown in atrial tissue during hypothyroidism (Freedberg, Papp, and Vaughan Williams, I970) and is the mode of action of amiodarone (Singh and Vaughan Williams, 1970).

Recently it was shown that patients with a tendency to relapse to atrial fibrillation after DC conversion to sinus rhythm had a fast atrial muscle Received 23 May 1973.

1 This study was supported by grants from Medical Research Council and The Swedish National Association against Heart and Chest Diseases. repolarization estimated from recordings of atrial monophasic action potentials (Olsson, Cotoi, and Varnauskas, 1971a) - recordings which, though not having the same amplitude, are representative of the real transmembrane action potential during the repolarization phase (Hoffman et al., 1959). The short monophasic action potential duration was thus an indication of a liability to arrhythmia in these patients. The present study was therefore initiated in order to study the action of a class 3 antiarrhythmic drug - amiodarone - on the atrial monophasic action potentials and the heart rhythm in patients with different kinds of atrial tachyarrhythmias.

\section{Subjects and methods}

Nine patients with different kinds of atrial tachyarrhythmias were included in the study. They were all treated earlier with other antiarrhythmic drugs but had failed to respond satisfactorily. Amiodarone had never been given to any of the patients before. Table I illustrates the age, sex, diagnosis, and medication in the individual patients. Without changing the earlier medical treatment which was believed to be optimal, the patients were investigated by recording their atrial monophasic action potentials using the percutaneous suction electrode technique, and using disposable monophasic action potential recording catheters ${ }^{2}$ (Olsson, Varnauskas, and ${ }^{2}$ ABO Trading, Dr. Lindhs, g. 6, S-413 45 Göteborg, Sweden. 
TABLE I Patients, clinical results, and side effects

\begin{tabular}{|c|c|c|c|c|c|c|}
\hline Case No. & $\begin{array}{l}\text { Age } \\
(y r)\end{array}$ & Sex & Diagnosis & Drug treatment & Clinical results & Side effects \\
\hline $\mathbf{I}$ & 50 & $\mathbf{M}$ & Parox. AF & $\begin{array}{l}\text { Digitalis; } \\
\text { amiodarone }\end{array}$ & $\begin{array}{l}\text { Decreased incidence of } \\
\text { attacks }\end{array}$ & $\begin{array}{l}\text { Corneal } \\
\text { opacifications }\end{array}$ \\
\hline 2 & 43 & $\mathbf{M}$ & Parox. AF & Amiodarone & $\begin{array}{l}\text { Complete abolition of } \\
\text { attacks }\end{array}$ & $\begin{array}{l}\text { Corneal } \\
\text { opacifications }\end{array}$ \\
\hline 3 & 52 & $\mathbf{F}$ & $\begin{array}{l}\text { Mitral stenosis operation; } \\
\text { rec. AF }\end{array}$ & $\begin{array}{l}\text { Digitalis; } \\
\text { frusemide; } \\
\mathrm{KCl} \text {; } \\
\text { dicoumarol; } \\
\text { amiodarone }\end{array}$ & SR 5 months & $\begin{array}{l}\text { Corneal } \\
\text { opacifications }\end{array}$ \\
\hline 4 & 40 & $\mathbf{M}$ & $\begin{array}{l}\text { Mitral stenosis operation; } \\
\text { rec. AF; } \\
\text { epilepsy }\end{array}$ & $\begin{array}{l}\text { Digitalis; } \\
\text { dicoumarol; } \\
\text { phenytoin; } \\
\text { primidone; } \\
\text { amiodarone }\end{array}$ & $\begin{array}{l}\text { SR maintained (at least } \\
8 \mathrm{mth})\end{array}$ & No \\
\hline 5 & 57 & $\mathbf{M}$ & $\begin{array}{l}\text { Old myocardial infarction; } \\
\text { parox. AF }\end{array}$ & Amiodarone & No effect & $\begin{array}{l}\text { Corneal } \\
\text { opacifications }\end{array}$ \\
\hline 6 & 47 & $\mathbf{M}$ & Rec. AF & $\begin{array}{l}\text { Digitalis; } \\
\text { practolol; } \\
\text { amiodarone }\end{array}$ & $\begin{array}{l}\text { SR maintained (at least } \\
5 \mathrm{mth})\end{array}$ & $\begin{array}{l}\text { Corneal } \\
\text { opacifications }\end{array}$ \\
\hline 7 & 76 & $\mathbf{F}$ & Parox. AF & $\begin{array}{l}\text { Digitalis; } \\
\text { phenytoin; } \\
\text { dicoumarol; } \\
\text { amiodarone }\end{array}$ & $\begin{array}{l}\text { Complete abolition of } \\
\text { attacks }\end{array}$ & No \\
\hline 8 & 54 & $\mathbf{F}$ & $\begin{array}{l}\text { Parox. AF; } \\
\text { hypertonia }\end{array}$ & $\begin{array}{l}\text { Alprenolol; } \\
\text { digitalis; } \\
\text { chlorthalidone; } \\
\mathrm{KCl} \text {; } \\
\text { amidarone }\end{array}$ & $\begin{array}{l}\text { Decreased frequency of } \\
\text { attacks }\end{array}$ & No \\
\hline 9 & 45 & $\mathbf{M}$ & $\begin{array}{l}\text { CMP; } \\
\text { rec. AF }\end{array}$ & $\begin{array}{l}\text { Digitalis; } \\
\text { dicoumarol; } \\
\text { amiodarone }\end{array}$ & $\begin{array}{l}\text { SR maintained (at least } \\
2 \mathrm{mth} \text { ) }\end{array}$ & No \\
\hline
\end{tabular}

Parox. AF = attacks of atrial fibrillation which spontaneously relapse to sinus rhythm.

Rec. AF = atrial fibrillation not relapsing spontaneously.

SR = sinus rhythm.

CMP = cardiomyopathy.

$\mathrm{KCl}=$ potassium chloride.

Korsgren, 1971b). The 4 patients who were converted by direct current shock to sinus rhythm from atrial fibrillation were investigated with monophasic action potential recordings in direet connexion with the conversion. After this recording, amiodarone was added to the earlier medication in a dose of $200 \mathrm{mg} 3$ times daily for one week, thereafter $200 \mathrm{mg}$ once daily. A second atrial monophasic action potential recording was then obtained at least 4 weeks after amiodarone treatment had started. There was no other change of treatment during this time. The clinical effects and the side effects of the regimen were also assessed from 4 weeks after amiodarone treatment was started and subsequently. Microscopical examination of the cornea was done before amiodarone treatment as well as $I$ and 6 months thereafter.

\section{Results}

Antiarrhythmic effect

The clinical effect of amiodarone as assessed from after 4 weeks' treatment and subsequently is shown in Table $\mathrm{I}$. Of the 9 patients, 8 had subjective or objective improvement of their arrhythmias. In the 5 patients with paroxysmal atrial fibrillation, the assessment of the effectiveness of the drug was based on the number of attacks experienced by the patient. In the 4 patients who were converted from atrial fibrillation by DC shock, the effect of treatment was good as they all stayed in sinus rhythm for a longer time than after earlier DC conversion: they had all relapsed to atrial fibrillation within I month after DC conversion on earlier occasions. Only I patient (Case 3 ) has so far relapsed into atrial fibrillation during treatment with amiodarone, 5 months after the treatement was started.

\section{Side effects}

Corneal opacification appeared in 5 patients and was the reason for discontinuing treatment in 2 
patients (Cases I and 3). No other side effects were noted.

\section{Monophasic action potential recording}

Right atrial monophasic action potentials could be recorded in 8 patients after treatment with amiodarone. In Case I, the corneal opacification led to discontinuation of the treatment before the second monophasic action potential recording could be performed. In all the other 8 patients, the right atrial monophasic action potential was prolonged, from averages of $234 \mathrm{msec}$ to $308 \mathrm{msec}$. The monophasic action potential prolongation was statistically significant $(P<0.005)$ according to the $t$ test of paired differences. Fig. I depicts recordings of electrocardiogram, monophasic action potential, and right atrial electrogram before and after 4 weeks of treatment with amiodarone (Case 3). The prolongation of the atrial monophasic action potential is further illustrated in Fig. 2 where the atrial potentials before and after amiodarone treatment have been superimposed so that they can be directly compared.

Table 2 illustrates the individual values of monophasic action potential duration from all recordings. It also shows that the heart cycle length has become longer after 4 weeks of amiodarone treatment.

\section{Discussion}

Of 5 patients with paraoxysmal atrial fibrillation, 4 improved with treatment, so that 2 of them had no further attacks after 3 weeks of treatment. Amiodarone also prevented relapse to atrial fibrillation after DC conversion in all 4 patients. The antiarrhythmic effect of amiodarone in this study agrees with the findings of other studies, where it has proved effective in various kinds of paroxysmal or chronic atrial tachyarrhythmias (Van Schepdael and Solvay, 1970; Garrigues, 1971). It must, however, be remembered that neither the present, nor any of the above cited studies has been controlled with randomization to alternative treatments. In the present study, most patients have, in addition, had a combination of other antiarrhythmic drugs.

We have noted corneal opacification in 5 of the 9 patients. Careful observations in larger series have revealed that such opacifications appear in nearly all patients (Pochulu, 1970; Vérin et al., 1971), when they are given $600 \mathrm{mg}$ amiodarone daily. The nature of these changes is still unknown (Pochulu, 1970; Vérin et al., 197I). Often they do not cause functional disturbances (Pochulu, 1970; Vérin et al., 197I) and are slowly reversible after the drug is discontinued (Pochulu, 1970; Vérin et al., 1971). In spite of this, we have hestitated to continue

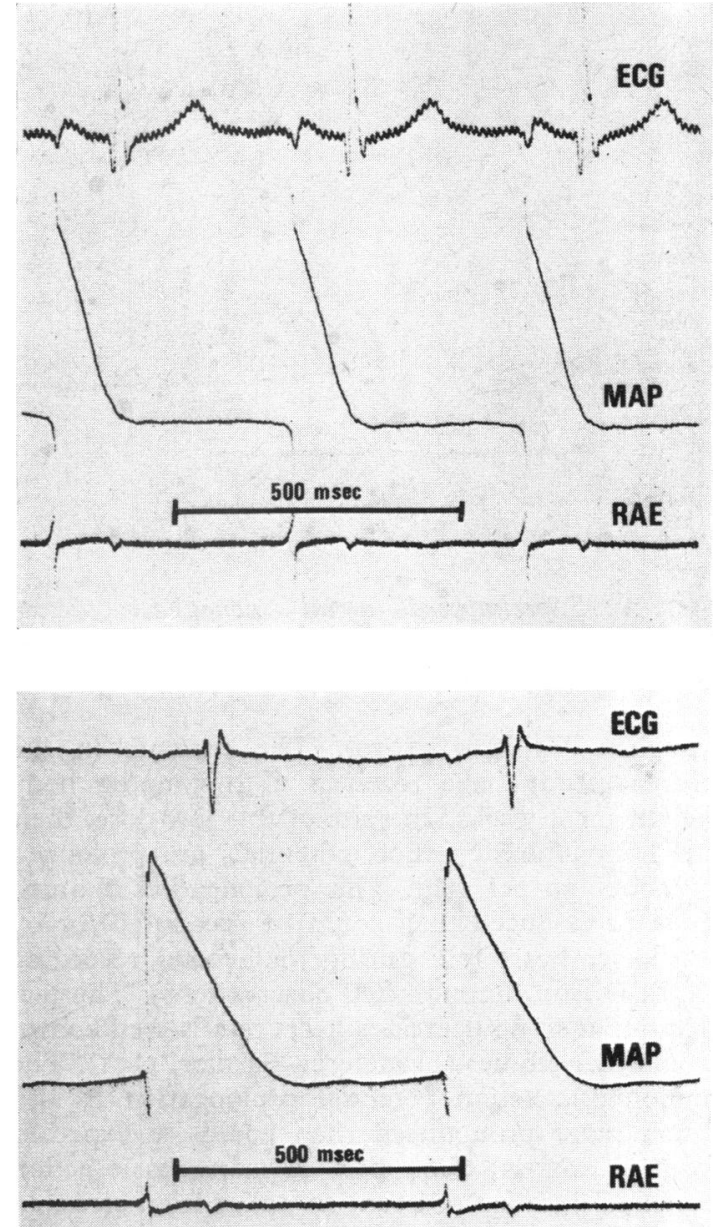

FIG. I Electrocardiogram (ECG), right atrial monophasic action potential $(M A P)$, and unipolar right atrial electrogram (RAE) before (upper) and 4 weeks after (lower) treatment with amiodarone (Case 3). The second recording shows a lower heart rate and a pronounced prolongation of the atrial monophasic action potential.

amiodarone treatment in 2 patients. Our choice of a daily maintenance dose of only $200 \mathrm{mg}$ is also based on the finding that few patients who are treated with this dose develop corneal opacification and only then to a lesser degree (Pochulu, 1970; Vérin et al., 1971).

When rabbits have been treated with amiodarone in a dose of $20 \mathrm{mg}$ per $\mathrm{kg}$ body weight for 6 weeks, they exhibit a prolongation of the atrial muscle action potential of about 30 per cent (Singh and 


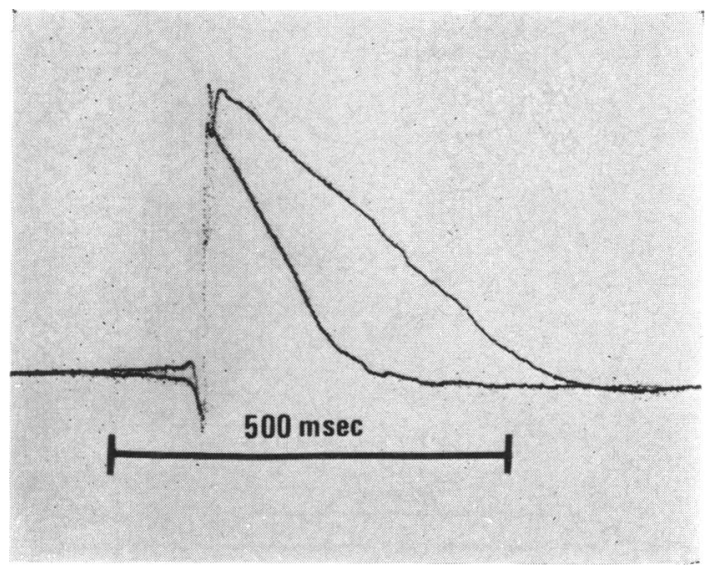

FIG. 2 Superimposed atrial monophasic action potentials, showing effect of amiodarone on atrial repolarization.

Vaughan Williams, 1970). The patients in the present study have received 2 to $3 \mathrm{mg} / \mathrm{kg}$ body weight for 4 weeks. In spite of this low dose, their atrial monophasic action potentials are prolonged by about 30 per cent. This prolongation is much more pronounced than could be accounted for by the lower heart rate during the second recording (S. B. Olsson, unpublished observations). The fact that amiodarone decreases heart rate is well known from other studies (Franchiset-Garnier, 197I). The monophasic action potential prolongation is also much more pronounced than could be expected from intra-atrial differences in monophasic action potential duration (Olsson, 1971a) or from errors in the measurement of the monophasic action potential (Olsson, 1972). It is thus obvious that the effect of amiodarone prolonging the atrial muscular action potentials, previously demonstrated, also takes place in human beings given the drug in clinical doses.

In vitro studies have shown that amiodarone also prolongs the action potential of rabbit ventricular muscle about as much as that of the atrial muscle (Singh and Vaughan Williams, 1970). As the QT time can be used for interpretation of the duration of the ventricular monophasic action potential duration (Olsson, 1972), and as amiodarone prolongs the QT interval (Franchiset-Garnier, 1971), it is likely that there is a prolongation of the human ventricular monophasic action potential as well after treatment with amiodarone.

It has been reported that the range of atrial monophasic action potential duration in 29 patients who had never had any atrial dysrythmia was 2 ro to $413 \mathrm{msec}$ (Olsson). In the present study, several patients had monophasic action potential durations which were lower than, or close to the lower limit of those found in the arrhythmia-free population. As a short atrial monophasic action potential duration, reflecting a short refractory period, clearly predisposes to arrhythmia, these patients should theoretically benefit most from treatment with a Class 3 antiarrhythmic drug. Recording of the atrial monophasic action potential may therefore be valuable in choosing the type of antiarrhythmic drug to use in individual patients.

The difficulties in comparing the results from in vitro experiments with the effect of a drug in clinical trials can obviously be partly overcome by using monophasic action potential recording techniques. The direct effect on cardiac muscle repolarization of drugs with a Class 3 mode of action can be accurately assessed with this technique. Assessment of Class I

TABLE 2 Cycle length and atrial monophasic action potential duration before and after at least 4 weeks' treatment with amiodarone

\begin{tabular}{|c|c|c|c|c|}
\hline Case No. & $\begin{array}{l}\text { Before amiod } \\
\text { Cycle length } \\
\text { (msec) }\end{array}$ & $\begin{array}{l}\text { Monophasic action } \\
\text { potential duration } \\
\text { (msec) }\end{array}$ & $\begin{array}{l}\text { After amiodaro } \\
\text { Cycle length } \\
\text { (msec) }\end{array}$ & $\begin{array}{l}\text { Monophasic action } \\
\text { potential duration } \\
\text { (msec) }\end{array}$ \\
\hline $\mathbf{I}$ & 830 & 270 & No recording & \\
\hline 2 & 933 & 255 & 1045 & 306 \\
\hline 3 & 805 & 170 & 1015 & 365 \\
\hline 4 & 792 & 259 & 805 & 283 \\
\hline 5 & 985 & 250 & 1115 & 285 \\
\hline 6 & 687 & 202 & 1005 & 232 \\
\hline 7 & 1086 & 207 & 1091 & 304 \\
\hline 8 & 1046 & 334 & 1200 & 427 \\
\hline 9 & 650 & 195 & 908 & 262 \\
\hline $\begin{array}{l}\text { Mean values } \\
\text { (Cases 2-9) }\end{array}$ & 873 & 234 & 1023 & 308 \\
\hline
\end{tabular}


activity cannot, however, be done from monophasic action potential recordings (Olsson, 197Ib).

\section{References}

Franchiset-Garnier, Marie-Josèphe (197I). Modifications electrocardiographiques provoquées par l'amiodarone (Cordarone), Thesis, Université Rene Descartes, Necker. Paris.

Freedberg, A. S., Papp, J. Gy., and Vaughan Williams, E. M. (1970). The effect of altered thyroid state on atrial intracellular potentials. Fournal of Physiology, 207, 357.

Garrigues, P. (197I). Etude Clinique du Chlorhydrate d'Amiodarone (Cordarone) dans les Troubles du Rythme Cardiaque. Régionale, Toulouse.

Hoffman, B. F., Cranefield, P. F., Lepeschkin, E., Surawicz, B., and Herrlich, H. C. (I959). Comparison of cardiac monophasic action potentials recorded by intracellular and suction electrodes. American fournal of Physiology, 196(6), I297.

Ling, G., and Gerard, R. W. (1949). The normal membrane potential of frog sartorius fibers. Fournal of Cellular and Comparative Physiology, 34, 383.

Olsson, S. B. (1971a). Monophasic action potentials from right atrial muscle recorded during heart catheterization. Acta Medica Scandinavica, 190, 369.

Olsson, S. B. (197rb). Monophasic Action Potentials of Right Heart. Suction Electrode Method in Clinical Investigations. Elanders Boktryckeri AB, Göteborg.

Olsson, S. B. (1972). Right ventricular monophasic action potentials during regular rhythm. Acta Medica Scandinavica, 191, 145 .
Olsson, S. B., Cotoi, S., and Varnauskas, E. (I971a). Monophasic action potential and sinus rhythm stability after conversion of atrial fibrillation. Acta Medica Scandinavica, 190, 381 .

Olsson, S. B., Varnauskas, E., and Korsgren, M. (197Ib). Further improved method for measuring monophasic action potentials of the intact human heart. Fournal of Electrocardiology, 4, 19.

Pochulu, Anne-Marie (1970). Thésaurismose Cornéenne par Cardarone - Intégrité Sémiologique des Autres Structures Oculaires Déductions Physiopathologiques et Prophylactiques. G. Sautai \& Fils, Talence-Bordeaux.

Singh, B. N., and Vaughan Williams, E. M. (1970). The effect of amiodarone, a new anti-anginal drug, on cardiac muscle. British fournal of Pharmacology, 39, 657.

Van Schepdael, J., and Solvay, H. (1970). Etude clinique de l'amiodarone dans les troubles du rythme cardiaque. Presse Médicale, 78, 1849.

Vaughan Williams, E. M. (1973). The development of new antidysrhythmic drugs. Schweizerische medizinische Wochenschrift, 103, 262.

Vérin, Ph., Gendre, Ph., Barchewitz, G., Laurent-Bronchat, G., Yacoubi, M., and Morax, S. (197I). Thésaurismose cornéenne par amiodarone. Archives d'Ophtalmologie et Revue Générale d'ophtalmologie, 31, 581.

Requests for reprints to Dr. S. Bertil Olsson, Department of Cardiology, Medical Clinic I, Sahlgrenska Hospital, S-413 45 Göteborg, Sweden. 